\title{
Comprehensive Medication Management Services as a Solution to Medication Mismanagement: A European Perspective
}

Iva Mucalo $^{1}$ D , Andrea Brajković ${ }^{1}$, Ivona Jukic ${ }^{2}$, Danijela Jonjić ${ }^{1}$, Dagmar Radin ${ }^{3}$, Antonija Balenovićc ${ }^{4}$ Djenane Ramalho de Oliveira ${ }^{5}$

\author{
${ }^{1}$ University of Zagreb Faculty of Pharmacy and Biochemistry, A. Kovacica 1, Zagreb, Croatia \\ ${ }^{2}$ Community pharmacy Mandis Pharm, Branimirova ulica 65, Zagreb, Croatia \\ ${ }^{3}$ University of Zagreb Faculty of Political Science, Lepusiceva 6, Zagreb, Croatia \\ ${ }^{3}$ Health Centre Zagreb Centar, Runjaninova 4, Zagreb, Croatia \\ ${ }^{4}$ Centre for Pharmaceutical Care Studies (Centro de Estudos Atencao Farmaceutica), Federal University of Minas Gerais, \\ Belo Horizonte, MG, Brazil
}

\section{ABSTRACT:}

Due to an increase in the prevalence of chronic diseases, medication use and their cost is rising rapidly. This scenario render chronic patients at an increased risk of experiencing drug therapy problems, subsequently leading to unfavourable clinical and economic outcomes. Thus, to ensure patients' optimal medication use and improve their clinical outcomes, a comprehensive and systematic management of medications is deemed crucial. Hence, Comprehensive Medication Management (CMM) services offered by trained pharmacists can fill this gap by decreasing the unnecessary and often harmful use of medicines and consequent resulting complications. Collaborative practice between pharmacists and general practitioners, together with patients' active participation in the definition of treatment regimens, plays an important role in the effectiveness of CMM services. CMM services is defined as the standard of care that ensures each patient's medications (prescription, non-prescription, alternative, traditional, vitamins, or nutritional supplements) are individually assessed to determine that each medication is appropriate for the patient, effective for the medical condition, safe given the comorbidities and other medications taken, and that the patient is able to take them as intended. It includes an individualized care plan that achieves the intended goals of therapy with appropriate follow-up to determine actual patient outcomes.

Apart from the USA, several countries (e.g. Australia, Canada and Brazil) have managed to integrate CMM services

OPEN ACCESS

Correspondence:

Iva Mucalo MPharm, PhD

PG Dip Pharm Pract

imucalo@pharma.hr orcid.org/0000-0002-5566-9356

This article was submitted to RAD CASA - Medical Sciences as the review article

Conflict of Interest Statement: The authors declare that

the research was conducted in the absence of any commercial or financial relationships that could be construed as a potential conflict of interest.

Received: 5 October 2019 Accepted: 20 November 2019 Published: 17 December 2019

Citation:

Mucalo I, Brajković A, Jukić I, Jonjić $D$, Radin D, Balenović A, de Oliveira DR. Comprehensive Medication Management Services as a Solution to Medication Mismanagement: European Perspective. RAD CASA - Medical Sciences. 540 $=48-49$ (2019): 33-40. https://dx.doi. 019): 33-40. https://dx.doi org/10.21857/90836cwv2y

Copyright (C) 2019 Mucalo, Brajković, Jukić, Jonjić, Radin Balenovic and de Oliveira. This is an open-access article distributed under the terms of the Creative Commons Attribution License (CC BY). The use, distribution or reproduction in other forums is permitted provided forums is permitted, provided

the original author(s) and the copyright owners(s) are credited and that the original publication in
this journal is cited, in accordance whit accepted adacemic practice. No use, distribution or reproduction is permitted which does not comply with these terms. into their existing health care system at the primary care level. However, in Europe, in spite of the widespread recognition of the need for medication management services, initiation and implementation of CMM services are lagging behind. Hence, for CMM services to become a reality in Europe and elsewhere, numerous prerequisites need to be accomplished, including policies and legal regulations supporting the provision of CMM services on a much larger scale, clearly defined and standardized professional practice and common language shared among the pharmacists, and well trained and experienced practitioners providing full-time, direct patient care.

KEYWORDS: medication management, comprehensive medication management services, chronic diseases, pharmaceutical care

\section{SAŽETAK:}

SVEOBUHVATNA USLUGA UPRAVLJANJA FARMAKOTERAPIJOM KAO RJEŠENJE ZA PROPUSTE U PROPISIVANJU LIJEKOVA: EUROPSKA PERSPEKTIVA

Zbog porasta prevalencije kroničnih bolesti, potrošnja lijekova ubrzano raste. Uslijed toga, kronični bolesnici su izloženi povećanom riziku pojave terapijskih problema što dovodi do nepovoljnih kliničkih i ekonomskih ishoda liječenja. Stoga se smatra da je sveobuhvatno i sustavno upravljanje farmakoterapijom ključno za osiguranje optimalne uporabe lijekova kao i za poboljšanje kliničkih ishoda liječenja. Sveobuhvatna usluga upravljanja farmakoterapijom (engl. Comprehensive Medication Management Services, CMM services) koju provode posebno educirani ljekarnici može ponuditi rješenje za ovaj problem, smanjujući nepotrebnu, a često i štetnu primjenu lijekova te njene posljedične komplikacije. Kolaborativna praksa ljekarnika i liječnika obiteljske medicine, koja uključuje i aktivno sudjelovanje pacijenata u kreiranju terapijskih režima, važan je čimbenik koji doprinosi učinkovitosti CMM usluge. CMM usluga se definira kao standard skrbi koji osigurava da se svakom pacijentu pojedinačno procjenjuju svi lijekovi (u receptnom ili bezreceptnom režimu, biljni, tradicionalni), vitamini ili dodaci prehrani koje uzima, kako bi se za svaki od njih utvrdilo je li prikladan za pacijenta, je li učinkovit za pacijentovo zdravstveno stanje, je li siguran s obzirom na komorbiditete i druge lijekove koje pacijent uzima, te je li pacijent sposoban i u mogućnosti uzimati lijekove kako treba. Usluga sadrži individualizirani plan skrbi kojim se postižu predviđeni ciljevi terapije kao i odgovarajuće praćenje (follow-up) kako bi se utvrdili stvarni ishodi liječenja.

Pored SAD-a, nekoliko je drugih zemalja (Australija, Kanada i Brazil) uspjelo integrirati CMM uslugu u svoje postojeće sustave primarne zdravstvene zaštite. Međutim, u Europi, unatoč raširenosti spoznaje o potrebi za upravljanjem farmakoterapijom, razvoj i implementacija CMM usluge zaostaje. Kako bi se CMM usluge realizirale u Europi i ostalim zemljama, potrebno je ispuniti brojne preduvjete, uključujući donošenje politika i zakonskih propisa koji podržavaju pružanje CMM usluga u mnogo većem obimu, ostvarivanje jasno definirane i standardizirane profesionalne prakse i zajedničkog jezika ljekarnika, te stvaranje dobro educiranih i iskusnih ljekarnika koji u punom radnom vremenu pružaju izravnu skrb pacijentima.

KLJUČNE RIJEČI: upravljanje farmakoterapijom, sveobuhvatna usluga upravljanja farmakoterapijom, kronične bolesti, ljekarnička skrb 


\section{INTRODUCTION}

According to the 2018 World Health Organization Country Profiles, noncommunicable diseases are the leading cause of death globally, and one of the major health challenges of the $21^{\text {st }}$ century ${ }^{1}$. In 2016, they were responsible for $71 \%$ ( 41 million) of the deaths globally, with cardiovascular diseases, cancers, chronic respiratory diseases and diabetes being the major causes ${ }^{1}$. Due to an increase in the prevalence of chronic illnesses, the number of prescriptions as well as their cost is rising rapidly $y^{2,3}$. The latest OECD publication "Health at a Glance: Europe 2018" states that pharmaceuticals expenditure represents the third largest item of health care spending in the European Union (EU), with Croatia having one of the highest expenditures on medical goods (mainly pharmaceuticals) among the EU Member States ${ }^{4}$. Moreover, an ample evidence base suggests that patients are often inadequately treated or not offered therapies that are likely to bring benefit ${ }^{4,5}$. Consequently, patients are at an increased risk of experiencing drug therapy problems (DTPs) which, if not resolved, have substantial unfavourable clinical repercussions and add substantial costs to the health care system ${ }^{6-8}$.

One way to address these issues is by improving the health-care system delivery and medication management. This includes, but is not limited to, the use of multidisciplinary care teams to provide coordinated care and ensure safe and effective pharmacotherapy to patients?. Comprehensive Medication Management (CMM) services offered by trained pharmacists can fill this gap by decreasing the unnecessary and often harmful use of medicines and consequent resulting complications $^{2,10-13}$

Today there is a widely accepted notion that a patient care process must involve a professional who is capable of applying a logical, standardized and reproducible process to pharmacotherapy decisions ${ }^{14}$. When medications were fewer in number, less complicated and more manageable, physicians were able to fulfil this responsibility. However, this is no longer true. CMM services are supported by a vast evidence-based literature ${ }^{6,10-13,15}$ and grounded in the practice of pharmaceutical care, as proposed by Cipolle, Strand and Morley ${ }^{14,16,17}$. It is also promoted by several organizations such as the American College of Clinical Pharmacy ${ }^{18,19}$, Get the Medications Right Institute ${ }^{20}$, and Patient-Centered Primary Care Collaborative, which includes more than 500 organisations, all active stakeholders in the health-care sys$\mathrm{tem}^{2}$. Thus, this service has a scientific and clinical base that attempts to systematize the work of the clinical pharmacist with the patient and in collaboration with other providers, in order to optimize the use of medications in individuals' daily lives.

\section{The Need for Medication Management Services}

Over the past few decades, the use of medications has undergone significant changes ranging from increases in prescription numbers, increases in the number and type of practitioners with prescribing rights, rising costs of new medications, to the rise in the increasingly complex new and emerging therapies. Another important factor worth mentioning is the continued lack of a structured, systematic decision-making process for drug selection and dosing ${ }^{14}$.

Existing evidence suggests that as much as one-fifth of all health spending is wasteful and could be reduced, or eliminated, without undermining health system performance ${ }^{21}$. In fact, after inpatient and outpatient care, pharmaceuticals (excluding those used in hospitals) represented the third largest health care expense, accounting for one sixth of all health expenditure in the EU in 2016. The total retail pharmaceutical bill across the EU was more than EUR 210 billion in 2016, representing an increase of approximately 5\% (in nominal terms) since 2010. In Croatia, prescription medications accounted for $87-90 \%$ of all medications financial costs from 2012 to 2016, growing about $3.5 \%$ annually, and reaching its peak of $10.2 \%$ in 2016 (22). These trends indicate a need to manage the use of prescription medications more efficiently.

Inadequate medication management has other consequences, such as increased levels of drug-related morbidity and mortality, which are directly responsible for health care costs, and call for health-care system reform ${ }^{14}$.

According to the latest data, more than 1.2 million people in EU countries died in 2015 from diseases and injuries that could have been avoided either through stronger public health policies or more effective and timely health care ${ }^{4}$. Additionally, potentially avoidable hospital admissions for some chronic conditions, out of which diabetes, hypertension, heart failure, chronic obstructive pulmonary disease (COPD) and bronchiectasis and asthma stand out, consume over 37 million bed days each year ${ }^{23}$. Over 4.6 million admissions were made for these five conditions in 2015, amounting to $5.6 \%$ of all admissions which might have been avoided ${ }^{4}$. The estimated annual cost of drug-related morbidity and mortality resulting from nonoptimized medication therapy in the United States (US) was $\$ 528.4$ billion, equivalent to $16 \%$ of total US health care expenditures in $2016^{6}$. Thus, governments and health plans pay for poor adherence to treatment, the lack of control of chronic diseases, and the development of complications in the long term. Additionally, in cases of multiple comorbidities, visits to different medical specialists concurrently, and without coordination or communication among them, often contribute to the worsening of medication related problems.

Hence, the expansion of CMM programs led by clinical pharmacists in collaboration with physicians and other licensed prescribers has been recommended in the United States as an effective and scalable approach to mitigate these avoidable costs and improve patient outcomes ${ }^{6}$.

\section{Medication Management Services as a Solution to the PROBLEM}

\section{A definition of medication management services}

Comprehensive medication management services is defined as the standard of care that ensures each patient's medications (whether they are prescription, nonprescription, alternative, traditional, vitamins, or nutritional supplements) are individually assessed to determine that each medication is appropriate for the patient, effective for the medical condition, safe given the comorbidities and other medications taken, and that the patient is able to take them as intended ${ }^{2}$. The concept and definition of the service has evolved over the years. In 2003, the Center for Medicare and Medicaid Services recommended the provision of medication therapy management services as an additional new service required for patients receiving Medicare Part D benefits $^{2,24}$. There are a number of definitions for medication management services available, but today we rely on the definitions proposed by the Patient Centered Primary Care Collaborative ${ }^{2}$, American Medical Association $^{25}$, and the Minnesota State Legislature ${ }^{26}$.

CMM services is an evidence-based and patient-centered clinical practice, provided by pharmacist with an aim of preventing, identifying and resolving DTPs to optimize patients' medication experience and 
clinical outcomes. Through this rational and standardized process, the pharmacist reviews the medications used by the patient and identifies possible problems associated with the indication, effectiveness, safety and compliance with the pharmacotherapy treatment. In addition to the comprehensive assessment of patient's drug-related needs, CMM includes the development of an individualized care plan to determine desired goals of therapy with the patient, as well as appropriate follow-up to evaluate actual patient outcomes that result from the care plan. All of this occurs because the patient understands, agrees with, and actively participates in the treatment regimen, thus optimizing each patient's medication experience and clinical outcomes.

The CMM services delivered in a health centre has the following five elements in common: a) the service needs to be delivered directly to a specific patient (as opposed to performing a prescription review without seeing the patient); b) it must include an assessment of the patient's medication-related needs, followed by an individualized care plan and follow up; c) the care must be comprehensive, i.e. pharmaceutical care practitioner assesses all of the patient's medications (prescribed, over-the-counter, supplements, herbal remedies etc.), since medications interact with other medications and impact all medical conditions; d) the work of pharmacists needs to be coordinated with physicians and other team members: and e) the service is expected to add unique value to the care of the patient.

The interventions proposed within the CMM services are grounded in the philosophy and ethics of the professional practice of pharmaceutical care and delivered according to the standards of practice for the patient care process described by the practice ${ }^{14}$. Pharmaceutical care was defined in 1990 as a practice in which a pharmacist-practitioner is held responsible for patient's drug related needs and accountable for this commitment, providing rational drug therapy with the purpose of achieving positive patient outcomes ${ }^{27}$.

\section{How is CMM Delivered?}

CMM is a patient-centred clinical service offered by pharmacists specially trained to do so. The pharmacist works directly with the patient in collaboration with physicians and other members of the multidisciplinary health care team. Care is coordinated among providers and across systems of care as patients transition in and out of various settings. Detailed description of steps and activities that need to be completed in order to carry out complete CMM services, including the patient care process, is presented in Table 1 .

The three steps of the patient care process include a) the assessment of the patient, his or her medical problems, and drug therapies leading to the DTP identification, b) care plan development and c) follow-up evaluations. These steps are highly dependent upon each other, and the fulfilment of all steps is necessary to practice pharmaceutical care and to have positive impact on patient's medication experience. The assessment step in the patient care process is the most important of the three as it influences all other components of the patient care process. The primary purpose of the assessment is to determine to what extent the patient's drug-related needs are being met and if any DTPs are present, while the goal of the care plan development is to determine how to manage patients' medical conditions favourably with pharmacotherapy. Finally, follow-up evaluation aims to determine the actual outcomes of drug therapy for the patient, compare these results with the intended goals of therapy, determine the effectiveness and safety of pharmacotherapy, evaluate patient adherence, and establish the current status of the patient's medical conditions being managed with drug therapy ${ }^{14}$. All the steps in the care process of the CMM services must be documented in a manner that adds unique value to the care of the patient, and contain information about the patient, the clinical pharmacist's interventions and decisions, as well as the results achieved in the management of pharmacotherapy.

As all patient care providers need a structured, rational thought process for sound clinical decision retrieval, the Pharmacotherapy Workup was developed and adopted as a systematic problem-solving process, specific to the practice of pharmaceutical care. This process represents the cognitive work, taking place in the mind of the practitioner, and is used to identify, resolve, and prevent drug therapy problems (DTPs), establish therapy goals, select interventions and evaluate outcomes. As highlighted by Cipolle et $\mathrm{al}^{14}$, what makes a practitioner qualified to do her/his work is the application of a unique knowledge base and set of clinical skills by using a systematic thought process, and in the case of the pharmaceutical care practitioner, this unique knowledge base focuses on pharmacology, pharmacotherapy, and pharmaceutical care practice.

\section{The Value of Medication Management Services}

The benefits of CMM services are numerous and include improved clinical outcomes ${ }^{11,12,15,28-32}$, decreased medical costs ${ }^{17,32-34}$, better access to health care services, time-savings to other health care providers, reduced adverse drug events, as well as significant impact on the appropriateness, effectiveness, safety and compliance with medications ${ }^{18}$

The ability of CMM to improve patient outcomes and provide system-wide benefits has been well documented ${ }^{35}$. Early results from a high-risk population involving 1651 patients, seen during 4453 encounters, show positive results: the percentage of medical conditions at goal changed from $54 \%$ at baseline to $80 \%$ with the introduction of the service ${ }^{33}$. Furthermore, in a Medicare group of 706 patients, $28 \%$ were found to have ten or more DTPs. As these DTPs were identified and resolved, significant improvements in blood pressure control and cholesterol were documented with an average cost savings of over $1750 \$$ per patient ${ }^{2}$.

Various studies have demonstrated the positive impact of pharmacists' interventions in the management of chronic diseases, such as cardiovascular diseases (CVD) and diabetes, and improvement in patient care when pharmacists are located in primary care ambulatory clinics working side by side the physicians and nurses ${ }^{17}$. Particularly, the greatest improvement in patient's clinical outcomes receiving CMM services has been observed in patients with medical conditions that are extremely costly and are associated with the use of multiple medications (hypertension, diabetes, CVD, COPD) ${ }^{12,36,37}$. Hence, patients with these comorbidities are considered as great candidates to receive the service. According to the largest database published until now $^{14}$, the total number of 88,556 DTPs was identified and resolved in 22,694 patients receiving CMM services in a 4-year period. Out of 18,866 patients' medical conditions that were not at goal at their first visit to pharmaceutical care practitioner, $74 \%$ of conditions improved or remained the same after receiving CMM services (14). In a retrospective study from 2004, pharmaceutical care practitioners identified 3,407 DTPs in 2,985 patients during their patients' first assessment, out of which $61 \%$ had one or more DTPs identified and resolved. As a result of pharmaceutical care provision, in one third of patients, medical conditions improved ${ }^{17}$. Ramalho de Oliveira et 
al ${ }^{12}$ showed that pharmacists identified and addressed 38,631 DTPs among 9,068 patients during a 10 -year period, whereof $80 \%$ of DTPs were directly resolved with patients, without consulting physicians. More than a half of DTPs necessitated inclusion of a new medication or dosage increase, while only $16.5 \%$ were associated with non-adherence. Rao et al ${ }^{38}$ showed that $81 \%$ of patients' DTPs were resolved or well managed by pharmacists, while Borges et al ${ }^{39}$ resolved $62.7 \%$ of DTPs in patients with type 2 diabetes. Moreover, CMM services have shown the positive impact on individual CV risk factors: blood pressure $(12,28,31,40)$, glycated hemoglobin $(\mathrm{HbA1c})(30,31,39)$ and LDL cholesterol ${ }^{12,30,40}$.

Furthermore, studies have demonstrated the economic and social welfare of CMM services ${ }^{17,32,34,41}$. Patients receiving face-to-face CMM services had lower total health expenditures, with the reduction in total annual health expenditures exceeding the cost of providing CMM services by as high as $12: 1$, and with the average ratio of $3: 1$ to 5:1 (return on investment, ROI ) ${ }^{33}$. A report reviewing the team-based medication therapy management system in four clinics revealed that spending growth was $11 \%$ less in innovation clinics (team-based care that incorporates comprehensive medication therapy management) than that in 38 non-innovation clinics ${ }^{42}$. Furthermore, the median monthly health care costs per member, measured at five intervals over a 15-month period, were significantly lower in innovation than in non-innovation sites ${ }^{42}$. The Ashville project, involving community pharmacy based practitioners specially trained to address issues in patients with diabetes, asthma, CVD and depression, demonstrated a 4:1 ROI and a decrease in direct yearly average medical costs between $\$ 1200$ and $\$ 1872$ per patient ${ }^{32,43,44}$.

The value of this service has been recognized by patients who had the opportunity to use it as well as by physicians and other health care professionals, health plans, employers and payers. Firstly, it is worth mentioning that patients benefit not only from improved clinical outcomes, but also from having health care professionals who are willing and capable to understand their unique medication experience. Physicians profit by having pharmacotherapy experts managing complex therapies side by side, thus enabling them to have more time for diagnostics and quality medical care provision ${ }^{33,45}$. Finally, insurers pay only for medications that are appropriate, effective and safe for the patient, and are used as intended.

\section{Current Situation of CMM Services Across Europe}

Health systems across Europe have achieved remarkable progress in treating life-threatening diseases, yet more effective healthcare interventions are needed if we are to improve management of health problems in the community. While disparities in healthcare systems between the European countries persist, patient-centred practices, in which pharmacists are held accountable for patients' clinical outcomes, are still underdeveloped and lack inclusion at the primary care level. In Europe, in spite of the widespread recognition of the need for medication management services, initiation and implementation of CMM services are lagging behind. Limited published data on CMM services implementation ${ }^{46}$ confirms that this service has not been developed or recognized in Europe, as it has been in the Anglo-Saxon countries especially USA and Australia ${ }^{18,47,48}$. Although supported by relevant laws, it seems that governments have not taken an active interest in promoting a movement toward pharmacists playing a major role in primary health care. The following text will not provide an in-depth description of the current situation regarding the status of medication management services in Europe, as this has been fully described elsewhere ${ }^{14}$, but rather shed a light on recent advancements that have occurred across European countries.

Integration of clinical pharmacist into general practitioner (GP) services in Great Britain began in 2015 when the National Health Service (NHS) England instigated the initiative and partly funded over 400 clinical pharmacists to provide support to almost 700 GP surgeries and more than seven million patients ${ }^{49}$. To date, over 1,000 full time equivalent clinical pharmacists provide the service across the country with a further 1,500 pharmacist roles planned by $2020^{50,51}$. This far-sighted initiative came in response to considerations about general practice workforce capacity, where concerns about shortfalls in GP numbers have been raised ${ }^{52}$. However, it is unclear whether the patient care process proposed by Cipolle et al ${ }^{14,53}$ is used as the theoretical framework to take care of the patients.

Very recent publications from Iceland and Netherlands highlight the importance of developing pharmaceutical care practice separately from the dispensing process and in close cooperation with physicians, at the primary care level ${ }^{48,54}$. Netherlands is an interesting example of community pharmacy having a leading role in pharmaceutical care provision, with reimbursements for pharmaceutical care services being covered by the Dutch government and health insurance companies ${ }^{14}$. Although it appears that the prerequisites for the implementation of medication management services are in place, at present the employment of CMM services in primary care is suboptimal, if any ${ }^{54}$. Namely, pharmacists lack access to patient information, they are short of clinical knowledge and skills, and the working processes of pharmacists and general practitioners match poorly. Nevertheless, attempts have been made to integrate a non-dispensing pharmacist in general practice and the results demonstrated favourable outcomes. Albeit, the process of care they employed did not follow the patient care process proposed by Cipolle et al ${ }^{14,53}$.

Although Iceland undoubtedly embraced the concept of pharmaceutical care, medication management services are still limited, and serious efforts will need to be invested before further development can oc$\operatorname{cur}^{14}$. General practitioners are not familiar with pharmaceutical care and additionally no such service is offered in pharmacies or primary care settings. Efforts have been made to introduce pharmacist-led pharmaceutical care into primary care clinics in Iceland in collaboration with GPs, and results showed that GPs would now like to have access to a pharmacist on a daily basis ${ }^{48}$.

In Slovenia, consultations delivered by non-dispensing pharmacists as a part of medication review clinics started in 2012, and today they are running in over 30 health centres (altogether over 50 clinics available, however not running full time $)^{55}$. However, lack of published data on clinical outcomes of this service limits us in making comparisons and conclusions on its effectiveness.

Spain has made progress towards the provision of clinical services mainly in community pharmacies. Considering the lack of published literature, pharmacists do not seem to be involved in direct patient care in ambulatory clinics or in the provision of CMM services. However, some very important initiatives have been made to prepare pharmacists to provide CMM services and to foster these services. The "Universidad de San Jorge" in Zaragoza offers a master program in which students are trained to care for real patients in collaboration with other members of the care team, which creatively includes 


\begin{tabular}{|c|c|c|c|}
\hline & & STEPS AND ACTIVITIES & $\begin{array}{c}\text { HEALTH } \\
\text { PROFESSIONAL }\end{array}$ \\
\hline $\begin{array}{l}\text { PATIENT REFERRAL } \\
\text { AND RECRUITMENT }\end{array}$ & $\begin{array}{l}\text { a) } \\
\text { b) } \\
\text { c) } \\
\text { d) } \\
\text { e) } \\
\text { f) }\end{array}$ & $\begin{array}{l}\text { Identify patients who benefit most from the service: } \\
\text { Patients who have not reached their therapeutic goal } \\
\text { Patients taking very complex dosage regimens } \\
\text { Patients who are frequently readmitted to the hospital } \\
\text { Patients experiencing adverse drug reactions } \\
\text { Patients needing prevention therapy } \\
\text { Patients who are having difficulty to understand and follow their } \\
\text { medication regimen. }\end{array}$ & $\begin{array}{l}\text { General practitioners, } \\
\text { medical specialists, } \\
\text { pharmacists, self-referral, } \\
\text { other (nurses, } \\
\text { family/friend } \\
\text { recommendation) }\end{array}$ \\
\hline $\begin{array}{l}\text { THE PATIENT CARE } \\
\text { PROCESS } \\
\text { Assessment of the } \\
\text { patient's drug related } \\
\text { needs }\end{array}$ & $>$ & $\begin{array}{l}\text { Meet the patient and uncover patient's medication experience } \\
\text { (preferences, expectations and beliefs). } \\
\text { Collect patient specific information: demographic information, social } \\
\text { history (alcohol, tobacco, caffeine) and clinical information (relevant } \\
\text { medical history, medication history, current medication list including } \\
\text { prescription and over-the-counter medications, herbal remedies, } \\
\text { supplements and medications used for a limited period of time, and } \\
\text { relevant laboratory values) including allergies, side-effects and } \\
\text { immunizations. } \\
\text { Prioritize patients' active medical conditions and medication-related } \\
\text { needs. }\end{array}$ & $\begin{array}{l}\text { Pharmaceutical-care } \\
\text { practitioner }\end{array}$ \\
\hline $\begin{array}{l}\text { Identification of drug- } \\
\text { related problems }\end{array}$ & $>$ & $\begin{array}{l}\text { Determine that all the patient's medications are properly indicated, the } \\
\text { most effective available, the safest possible, and that the patient is able } \\
\text { and willing to take the medication as intended. } \\
\text { Analyse the assessment data to determine if any drug therapy problems } \\
\text { are present. }\end{array}$ & \\
\hline Care plan development & $>$ & $\begin{array}{l}\text { Identify goals of therapy for each indication managed with drug therapy. } \\
\text { Develop a care plan that includes interventions to resolve current drug } \\
\text { therapy problems, prevent potential drug therapy problems and achieve } \\
\text { goals of therapy. } \\
\text { Discuss and negotiate the care plan with the patient and his prescriber, } \\
\text { ensure patient's and prescriber's understanding and agreement with the } \\
\text { plan, and schedule follow-up evaluation. } \\
\text { Document the care plan which includes all the steps and clinical status } \\
\text { determined for every patient's medical condition. }\end{array}$ & \\
\hline Follow-up evaluation & $>$ & $\begin{array}{l}\text { Make follow-up evaluation for each patient to reassess whether any new } \\
\text { drug therapy problems have developed, monitor patient's progress } \\
\text { toward the achievement of the goals of therapy, and refine the care plan } \\
\text { to ensure therapy goals are achieved and medication therapy is } \\
\text { optimized. }\end{array}$ & \\
\hline $\begin{array}{l}\text { CARE COORDINATION } \\
\text { BY ALL TEAM } \\
\text { MEMBERS - } \\
\text { REPEATING PROCESS- } \\
\text { CARE }\end{array}$ & $>$ & $\begin{array}{l}\text { Collaborate and integrate with other health care providers such as } \\
\text { prescribers, medical specialists, pharmacists, care managers, and others, } \\
\text { with the purpose of achieving optimal care for the patient and assuring } \\
\text { all goals of therapy are understood by all team members. }\end{array}$ & $\begin{array}{l}\text { Pharmaceutical-care } \\
\text { practitioner, general } \\
\text { practitioner, medical } \\
\text { specialists and other (e.g. } \\
\text { nurses) }\end{array}$ \\
\hline
\end{tabular}


a psychologist, a philosopher and an anthropologist. Moreover, in 2012 the "Sociedad Española de Optimización de la Farmacoterapia (SEDOF)" was founded in Andalucía with the goal to congregate pharmacists interested in developing CMM services ${ }^{56}$. SEDOF promotes the "Escuela de optimización de la farmacoterapia", which is in its 14 th version. These courses include discussions on patient cases and reflect on specific aspects of patient care within the framework of CMM services.

Croatia is one of the countries where the implementation of comprehensive medication management services started only recently. Although Croatia embraces the concept of pharmaceutical care practice, policies and legal regulations supporting the provision of CMM services on a much larger scale, still need to be developed. According to the Law on Pharmacy ${ }^{57}$, Croatian pharmacists are obligated to provide pharmaceutical care in cooperation with other health care workers. However, the same Law ties pharmaceutical activities exclusively to community and hospital pharmacies, and precludes pharmacists from providing care at locations where their expertise is indispensable, such as nursery homes, health care centres and hospital wards. The abovementioned is only one of the existing legal obstacles that needs to be addressed prior to CMM services implementation. Nevertheless, pharmacy graduates in Croatia are competent in providing clinical services more than ever before, mainly due to the curriculum reform that has commenced in the academic year 2005/2006 due to which the focus has shifted from more chemically oriented pharmaceutical sciences toward clinically based and patient-focused courses. In order to harmonize our study programme with the EU Directive 2005/36/EC, Faculty of Pharmacy and Biochemistry University of Zagreb (UoZ) introduced an obligatory six-month traineeship and new modules (e.g. Pharmacotherapy and Clinical Pharmacy, Pharmaceutical Care, Consultation Skills, Health legislation, Sociology in Pharmacy etc.) in the academic year 2011/2012 (58). Furthermore, since the academic year 2010/2011, the postgraduate specialist study program "Clinical pharmacy" has been offered at the Faculty of Pharmacy and Biochemistry UoZ, and it precedes the 3-year Specialization in Clinical Pharmacy assigned from the Ministry of Health. All of these changes equipped Croatian pharmacists with clinical knowledge and skills needed for engaging in clinical activities. Nevertheless, up until now the government did not provide any standardized and legal framework allowing for the development of strategies to broaden pharmacists' responsibilities and expand those into the integrated health care system. Hence, pharmacists' educational requirements for CMM services provision in Croatia still need to be defined within the profession itself and subsequently legalized. On the bright side, a small group of younger pharmacists in Croatia is currently taking the lead and creating new services. The CMM services are piloted by two pharmacists from the UoZ Faculty of Pharmacy and Biochemistry at the primary care clinic, Health Centre Zagreb Centre, since January $2018^{46}$. Until now, this is the only county health centre providing CMM services at the primary care level in Croatia. This positive development, even if it is small, holds promise for the further progression of medication management services in Croatia.

The examples of the abovementioned countries showcase that a process of comprehensively and rationally managing patients' medications is not systematically implemented across European countries and that the countries are struggling to find the best solution in that endeavour. Due to disparate standing points, resulting from different cultural, sociolegal and ethical backgrounds, one cannot foresee a direction countries will take and the rate at which the change will be occurring.

In conclusion, for CMM services to become a reality in Europe and elsewhere, it is of paramount importance that pharmacists who will provide these services have one professional practice as their theoretical and ethical foundation. Thus, we will be able to teach to this practice and pharmacists will be able to communicate between themselves and to others what they do for patients. In addition, only then we will be able to evaluate the results of what we do, compare between ourselves and improve upon that. That is how all other members of the healthcare team work, which reflects the rules of patient care worldwide. Moreover, we will need policy to support the development and implementation of these services in a manner that can be reimbursed, reproducible and sustainable over time. What we really need are governments and health plans willing to support clinical pharmacists, namely professionals willing and capable to provide this service, as it will only live its full potential when we have well trained and experienced practitioners. To achieve this, clinical pharmacists need not only to expand their clinical knowledge by having experience with lots of patients, but also to reflect upon and assess these experiences. We will not have clinical experts until we have pharmacists that can provide direct patient care as a full-time job, caring for as many patients as possible. Only then will they gain expertise and exert their full potential. Consequently, we will know what this service is able to produce in terms of clinical outcomes and healthcare cost reduction. We cannot emphasize enough that the policy piece is key here. We need innovators, forward thinkers to support clinical pharmacists as they work on building their clinical practices and expertise. In the end, that is what patients deserve from us.

\section{AUTHOR CONTRIBUTIONS:}

All authors listed have made a substantial, direct and intellectual contribution to the work, and approved it for publication.

\section{LITERATURE:}

1. World Health Organization. Noncommunicable diseases key facts. 2018. Available at: https://www.who.int/news-room/fact-sheets/detail/ noncommunicable-diseases. Accessed September 11 th 2019

2. McInnis T, Strand L, Webb CE. Integrating Comprehensive Medication Management to Optimize Patient Outcomes. Resour Guid. 2012;A-26.

3. Institute of Medicine. Informing the Future: Critical Issues in Health: Fourth Edition. Washington DC: The National Academies
Press, 2007.

4. OECD/EU. Health at a Glance: Europe 2018: State of Health in the EU Cycle. Paris: OECD Publishing, 2018. doi: 10.1787/health_ glance_eur-2018-en.

5. Levine DM, Linder JA, Landon BE. The quality of outpatient care delivered to adults in the United States, 2002 to 2013. JAMA Intern Med. 2016; 176(12):1778-90. doi:10.1001/jamainternmed.2016.6217.

6. Watanabe JH, McInnis T, Hirsch JD. Cost of Prescription 
Drug-Related Morbidity and Mortality. Ann Pharmacother. 2018;52(9):829-37. doi: 10.1177/1060028018765159.

7. Ernst FR, Grizzle AJ. Drug-related morbidity and mortality: Updating the cost-of-illness model. J Am Pharm Assoc (Wash). 2001;41(2):192-9. doi: 10.1016/S1086-5802(16)31229-3.

8. Johnson JA, Bootman JL. Drug-related morbidity and mortality and the economic impact of pharmaceutical care. Am J Heal Pharm. 1997;54(5):554-8. doi: 10.1093/ajhp/54.5.554.

9. Wiedenmayer K, Summers RS, Mackie CA, Gous AGS, Everard M, Tromp D. Developing pharmacy practice - A focus on patient care. World Health Organization, International Pharmaceutical Federation, 2006.

10. Butler A, Dehner M, Gates RJ, Shane P, Chu M, DeMartini L, et al. Comprehensive Medication Management programs: 2015 status in Southern California. Res Soc Adm Pharm. 2017;13(1):63-87. doi: 10.1016/j.sapharm.2016.02.003.

11. Santos BD, Gonzaga do Nascimento MM, Batista de Oliveira GC, Nascimento YA, Mambrini JVM, Cid AS, et al. Clinical Impact of a Comprehensive Medication Management Service in Primary Health Care. J Pharm Pract. 2019;18:897190019866309. doi: 10.1177/0897190019866309. [cited 2019 Sep 23]. [Epub ahead of print].

12. Ramalho de Oliveira D, Brummel AR, Miller DB. Medication therapy management: 10 years of experience in a large integrated health care system. J Manag Care Pharm. 2010;16(3):185-95. doi: 10.18553/jmcp.2010.16.3.185.

13. Australian Medical Association. Analysis of non-dispensing pharmacists in general practice clinics. Sydney: Deloitte Access Economics, 2015.

14. Cipolle RJ, Strand LM, Morley PC. Pharmaceutical care practice: the patient-centered approach to medication management. 3rd ed. New York: McGraw-Hill, 2012.

15. Mendonça SAM, Melo AC, Pereira GCC, Serio dos Santos DMS, Grossi EB, Boas Sousa MCV, et al. Clinical outcomes of medication therapy management services in primary health care. Brazilian J Pharm Sci. 2016;52(3):365-73. doi: 10.1590/s198482502016000300002 .

16. Cipolle RJ, Strand LM, Morley PC. Pharmaceutical Care Practice. New York: McGraw- Hill, 1998.

17. Strand LM, Cipolle RJ, Morley PC, Frakes MJ. The impact of pharmaceutical care practice on the practitioner and the patient in the ambulatory practice setting: twenty-five years of experience. Curr Pharm Des. 2004;10:3987-4001. doi: 10.2174/1381612043382576. 18. McBane SE, Dopp AL, Abe A, Benavides S, Chester EA, Dixon DL, et al. Collaborative drug therapy management and comprehensive medication management - 2015. Pharmacotherapy. 2015;35:e3950. doi: $10.1002 /$ phar. 1563.

19. American College of Clinical Pharmacy. Comprehensive Medication Management in Team-Based Care. 2017. Available at: https:// www.accp.com/docs/positions/misc/CMM\%20Brief.pdf. Accessed September 12th 2019.

20. GTMR Institute. Get the medications right. 2019. Available at: https://gtmr.org/. Accessed September 12th 2019.

21. OECD. Tackling Wasteful Spending on Health. Paris: OECD Publishing, 2017. Available at: https://doi. org/10.1787/9789264266414-en. Accessed September 12th 2019. 22. Draganić P, Škribulja M, Oštarčević S. Potrošnja lijekova u Hrvatskoj 2012. - 2016. Agencija za lijekove i medicinske proizvode - HALMED. Available at: http://www.halmed.hr/fdsak3jnFsk1Kfa/ publikacije/Potrosnja-lijekova-u-RH_2012-2016.pdf. Accessed September 12th 2019.

23. Purdy S, Griffin T, Salisbury C, Sharp D. Ambulatory care sensitive conditions: terminology and disease coding need to be more specific to aid policy makers and clinicians. Public Health. 2009;123(2):169-73. doi: 10.1016/j.puhe.2008.11.001.

24. Public Law 108-173-DEC. 8, 2003, The Medicare Prescription Drug, Improvement, and Modernization Act of 2003. 2003. Available at: https://www.govinfo.gov/app/details/PLAW-108publ173. Accessed September 12th 2019.

25. American Medical Association. Current Procedural Terminology. Available at: https://www.ama-assn.org/amaone/cpt-current-procedural-terminology. Accessed September 12th 2019.

26. Minnesota statute 256B.0625 subd. 13h, 2005. Available at: https://www.revisor.mn.gov/statutes/ ?id=256B.0625. Accessed September 12th 2019.

27. Hepler CD, Strand LM. Opportunities and responsibilities in pharmaceutical care. Am J Hosp Pharm. 1990;47(3):533-43.

28. Planas LG, Crosby KM, Mitchell KD, Farmer KC. Evaluation of a hypertension medication therapy management program in patients with diabetes. J Am Pharm Assoc (2003) [Internet]. 2009;49(2):16470. doi: 10.1331/JAPhA.2009.08164.

29. Neves CM, Gonzaga do Nascimento MM, Silva DÁM, Ramalho de Oliveira D. Clinical Results of Comprehensive Medication Management Services in Primary Care in Belo Horizonte. Pharmacy (Basel). 2019;7(2):58. doi: 10.3390/pharmacy7020058.

30. Obreli-Neto PR, Guidoni CM, de Oliveira Baldoni A, Pilger D, Cruciol-Souza JM, Gaeti-Franco WP, et al. Effect of a 36-month pharmaceutical care program on pharmacotherapy adherence in elderly diabetic and hypertensive patients. Int J Clin Pharm. 2011;33(4):6429. doi: 10.1007/s11096-011-9518-x.

31. Mourão AO, Ferreira WR, Martins MA, Reis AM, Carrillo MR, Guimarães AG, et al. Pharmaceutical care program for type 2 diabetes patients in Brazil: a randomised controlled trial. Int J Clin Pharm. 2013;35(1):79-86. doi: 10.1007/s11096-012-9710-7.

32. Cranor CW, Bunting BA, Christensen DB. The Asheville Project: Long-term clinical and economic outcomes of a community pharmacy diabetes care program. J Am Pharm Assoc (Wash). 2003;43:173-84. doi: $10.1331 / 108658003321480713$.

33. Isetts BJ, Schondelmeyer SW, Artz MB, Lenarz LA, Heaton AH, Wadd WB, et al. Clinical and economic outcomes of medication therapy management services: the Minnesota experience. J Am Pharm Assoc (2003). 2008;48(2):203-11. doi: 10.1331/JAPhA.2008.07108. 34. Obreli-Neto PR, Marusic S, Guidoni CM, Baldoni Ade O, Renovato RD, Pilger D, et al. Economic evaluation of a pharmaceutical care program for elderly diabetic and hypertensive patients in primary health care: a 36-month randomized controlled clinical trial. J Manag Care Spec Pharm. 2015;21(1):66-75. doi: /10.18553/ jmcp.2015.21.1.66.

35. Giberson S, Yoder S, Lee MP. Improving Patient and Health System Outcomes through Advanced Pharmacy Practice. A Report to the U.S. Surgeon General. Office of the Chief Pharmacist. U.S. Public Health Service, 2011.

36. Detoni KB, Oliveira IV, Gonzaga do Nascimento MM, Caux TR, Alves MR, Ramalho de Oliveira D. Impact of a medication therapy management service on the clinical status of patients with chronic obstructive pulmonary disease. Int J Clin Pharm. 2017;39(1):95-103. doi: 10.1007/s11096-016-0402-6.

37. Rodis JL, Sevin A, Awad MH, Porter B, Glasgow K, Hornbeck Fox C, et al. Improving Chronic Disease Outcomes Through Medication Therapy Management in Federally Qualified Health Centers. J Prim Care Community Health. 2017;8(4):324-31. doi: $10.1177 / 2150131917701797$.

38. Rao D, Gilbert A, Strand LM, Cipolle RJ. Drug therapy problems found in ambulatory patient populations in Minnesota and South 
Australia. Pharm World Sci. 2007;29(6):647-54. doi: 10.1007/ s11096-007-9123-1.

39. Borges AP, Guidoni CM, Ferreira LD, de Freitas O, Pereira LR. The pharmaceutical care of patients with type 2 diabetes mellitus. Pharm World Sci. 32(6):730-6. doi: 10.1007/s11096-010-9428-3. 40. Bunting BA, Smith BH, Sutherland SE. The Asheville Project: Clinical and economic outcomes of a community-based long-term medication therapy management program for hypertension and dyslipidemia. J Am Pharm Assoc (2003). 2008;48(1):23-31. doi: 10.1331/ JAPhA.2008.07140.

41. Schultz H, Westberg SM, Ramalho de Oliveira D, Brummel A. Patient-perceived value of Medication Therapy Management (MTM) services : a series of focus groups. Inov Pharm. 2012;3(4):Article 96. doi: 10.24926/iip.v3i4.278.

42. Isetts BJ, Brummel AR, Ramalho de Oliveira D, Moen D. Managing Drug-related Morbidity and Mortality in the Patient-centered Medical Home. Medical Care. 2012;50(11):997-1001. doi: 10.1097/ MLR.0b013e31826ecf9a.

43. Cranor CW, Christensen DB. The Asheville Project: Factors Associated With Outcomes of a Community Pharmacy Diabetes Care Program. J Am Pharm Assoc. 2003;43(2):160-72. doi: $10.1331 / 108658003321480704$

44. Cranor CW, Christensen DB. The Asheville Project: Shortterm outcomes of a community pharmacy diabetes care program. J Am Pharm Assoc. 2003;43(2):149-59. Available from: doi: $10.1331 / 108658003321480696$.

45. Funk KA, Pestka DL, Roth McClurg MT, Carroll JK, Sorensen TD. Primary Care Providers Believe That Comprehensive Medication Management Improves Their Work-Life. J Am Board Fam Med. 2019;32(4):462-73. doi: 10.3122/jabfm.2019.04.180376.

46. Brajković A, Mucalo I, Vidović T, Gonzaga do Nascimento MM, Balenović A, Protrka I, et al. Implementation of medication management services at the primary healthcare level - a pilot study. Acta Pharm. 2019;69:585-606.

47. Butler A, Dehner M, Gates RJ, Shane P, Chu M, DeMartini L, et al. Comprehensive Medication Management Programs : 2015 Status in Southern California. 2016;13(1):63-87. doi: 10.1016/j. sapharm.2016.02.003

48. Blondal AB, Sporrong SK, Almarsdottir AB. Introducing Pharma- ceutical Care to Primary Care in Iceland-An Action Research Study. Pharmacy. 2017;5(2):23. doi: 10.3390/pharmacy5020023.

49. Torjesen I. More than 400 pharmacists will be recruited to GP surgeries by next year. BMJ. 2015;351:h6167. doi: 10.1136/bmj.h6167. 50. Sims L, Campbell J. Ills, pills, and skills: developing the clinical skills of pharmacists in general practice. Br J Gen Pract. 2017;67(662):417-18. doi:10.3399/bjgp17X692453.

51. Langran T, Nanda N, Bataveljic A, Gonzalez-Durio J. Supporting the management of type 2 diabetes with pharmacist-led reviews: An observational analysis. BMJ Open. 2017;7:e013451. doi: 10.1136/ bmjopen-2016-013451.

52. Centre for Workforce Intelligence. In-depth review of the general practitioner workforce. London: Centre for Workforce Intelligence. 2014 .

53. Haines ST, Kliethermes M, Sorensen TD. The Patient Care Process. In: DiPiro JT, Talbert RL, Yee GC, Matzke GR, Wells BG, Posey LM. eds. Pharmacotherapy: A Pathophysiologic Approach, 10th ed. New York: Mc-Graw-Hill, 2016. Available at: http://accesspharmacy. $\mathrm{mhmedical}$. com/content. aspx? bookid $=1861$ \&sectionid $=174720532$. Accessed September 12th 2019.

54. Hazen ACM, Wal AW, Sloeserwij VM, Zwart DLM, Gier JJ, Wit $\mathrm{NJ}$, et al. Controversy and consensus on a clinical pharmacist in primary care in the Netherlands. Int J Clin Pharm. 2016;38(5):1250-60. doi: $10.1007 / s 11096-016-0360-z$

55. Zavod za zdravstveno zavarovanje Sloveniji. Recept, Bilten o zdravilih iz obveznega zdravstvenega zavarovanja. 2017;Letnik 14/ št.1. Accessed September 12th 2019. from http://www.zzzs.si/ZZZS/ info/egradiva.nsf/0/ba51d225d7c16f2dc12581d9003c992e/\$FILE/ bilten\%20Recept_23.11.2017.pdf

56. Sociedad Española de Optimización de la Farmacoterapia. Available at: http://www.sedof.es. Accessed September 12th 2019.

57. The Constitution of the Republic of Croatia, The Official Gazette, Law on Pharmacy No 121/03, 142/06, 35/08, 117/08. 2003. Available at: https://www.zakon.hr/z/409/Zakon-o-ljekarni\%C5\%A1tvu. Accessed September 12th 2019.

58. Brajković A, Hadžiabdić MO, Mucalo I, Bach-Rojecky L, Pepić I, Vanić Ž, et al. Uvođenje Stručnog osposobljavanja za ljekarnike (SO) u studij Farmacije na Farmaceutsko-biokemijskom fakultetu Sveučilišsta u Zagrebu. Farm Glas. 2017;73:869-79. 